\title{
The Effect Of Leverage, Profitability, And Dividend Policy On Firm Value
}

\author{
Diah Ragil Saputri ${ }^{1 *}$, Syaiful Bahri² \\ ${ }^{1,2}$ Institute Technology And Business Asia Malang \\ ${ }^{*}$ Corresponding author: \\ E-mail: dideicassie@gmail.com
}

\begin{abstract}
This study aims to examine the effect of leverage, profitability, and dividend policy variables on firm value in property and real estate companies listed on the Indonesia Stock Exchange for the 2018-2020 period. This type of research is causal associative. The research population is 64 companies. The sample was determined by purposive sampling technique as many as 11 companies. Data analysis used multiple linear regression analysis. The test results show that leverage as proxied by debt to equity ratio (DER) has no significant effect on firm value, profitability proxied by return on equity (ROE) has a significant effect on firm value, and dividend policy proxied by dividend payout ratio (DPR) has no significant effect on the value of the company. Investors pay more attention to the company's ability to earn profits and its management.
\end{abstract}

Keywords: leverage, profitability, dividend policy, firm value

\section{INTRODUCTION}

In an increasing competitive era of industrialization, every company must continuously improve its competitiveness due to increasing competition in both domestic and international markets. Companies are required to be able to maintain or obtain high profits by paying attention to operational and financial activities. The short-term goal is to maximize profit by using existing resources, while the long-term goal is to maximize the value of the company. Firm value is the investor's perception of the company. The value of the company is reflected in the stock price which is stable in the long term has increased, the higher the stock price of a company, the higher the value of the company. According to [1] the higher the value of the company indicates that the company is able to improve its performance well. The value of the company is proxied by the stock price, so maximizing the value of the company is the same as maximizing the stock market price. The stock price is the right index to measure the value of the company. The value of the company that is formed through the stock market value indicator is strongly influenced by investment opportunities. The existence of investment opportunities published by the management in the form of financial statements gives a positive signal about the company's growth in the future so that it can increase the value of the company. This is in line with signal theory [2] that the executive, namely the company, has better information and will convey information to potential investors so that stock prices increase. Increasing the stock price means increasing the return that will be obtained by potential investors. [3] state that this theory reveals that investors can distinguish between companies that have high values and vice versa. Companies that have a high value will always improve their performance so that their value is higher and make potential investors invest as much as possible. Potential investors will be interested in investing in the company and will increase the share price.

In general, firm value is influenced by several factors. Based on previous research, firm value is influenced by several variables, including: leverage, profitability, liquidity, dividend policy, managerial ownership, institutional ownership, investment opportunity, and firm size. This study examines the effect of leverage, profitability, and dividend policy on firm value. Leverage to measure the company's ability to meet all short-term and long-term liability. Companies should balance the amount of debt and sources to pay debts. The amount of debt burden can reduce the amount of profit received so that it can reduce the value of the company. Leverage is proxied by the dept to equity ratio (DER). DER is the ratio between total liabilities and total equity. The higher the DER value, the higher the risks faced and have a negative impact on the value of the company. This is in accordance with the research of [4], [5], [6], [7], [8], [9], [10], and [11] that 
leverage has an effect on firm value. Different research results found [12], [13], [14], [15], [16], [17], [18], and [19] that leverage has no effect on firm value. The results of previous studies and theories explain that leverage has an effect on firm value. The investor's perception of investors is that leverage shows low returns, so it becomes a signal if the company has lower debt than internal capital. Vice versa, if leverage shows high results, investors will judge the company as having a low value because it has higher debt than its own capital. The relationship between leverage and firm value can be formulated as the first hypothesis: Leverage has a significant effect on firm value.

The profitability ratio measures the level of profit that can be obtained by the company. The higher the profit level, the better the management of a business. Profitability shows the amount of profit generated by the company. The condition of the company's ability to generate profits is an important signal for investors to make decisions. Profitability is an attraction for company owners and shareholders because profitability is the result obtained through management's efforts on the funds invested and profitability also reflects the distribution of profits that are due to them. Profitability is proxied by return on equity (ROE). ROE shows the amount of return on equity invested by investors with a comparison of net income and own capital. The higher the ROE value, the better the prospect of the company in the future for investors. This is in accordance with the research of [13], [7], [20], [21], [22], [18], [23], [16], [9], [19], [5] and [8] finding that the profitability ratio has an effect on firm value. Different research results found [17], [24], [12], [25], and [10] that the profitability ratio had no effect on firm value. The results of previous studies and theories explain that profitability has an effect on firm value. Information on increasing profitability will give a positive signal to investors. The greater the percentage obtained, the more effective the company is in utilizing assets to earn profits which will increase the value of the company, and vice versa. Investors will see the company's ability to generate profits. In accordance with signal theory, if profitability increases, it will give a positive signal to investors. High profitability will affect investors' interest in investing their capital. The relationship between profitability and firm value can be formulated as a second hypothesis: Profitability has a significant effect on firm value.

Dividend policy is one of the assessment factors for the company so that there needs to be a good decision making in dividend policy. Dividend policy is a decision whether the profits earned will be distributed to shareholders as dividends or will be retained in the form of retained earnings to finance investment in the future. Dividend policy refers to the rules determined by the company in determining the amount of profit allocated to be distributed to shareholders [26]. The distribution of dividends will make shareholders have additional returns other than capital gains, but if dividends are retained, they can be used for investment in the future. High dividend distribution can increase the value of the company. Dividend policy is proxied by the dividend payout ratio (DPR) [27]. Dividend payments are generally followed by an increase in stock prices and are seen as a signal that the company has good prospects. This indicates that dividend policy has a positive effect on firm value. In investing, investors need to collect information as one of the considerations in making investment decisions in the capital market. The higher the value of DPR, the higher the profitability of the company and the return that investors will receive. This is in accordance with the research results of [28], [18], [29], [22], [30], [24], [31], [32], [9], [12], [18], [33], [27], [14], and [34] that dividend policy affects firm value. Different research results found [17], [13], [35], [16], and [5] that dividend policy had no effect on firm value. The results of previous studies and theories explain that dividend policy has an effect on firm value. Information on increasing dividend policy will give a positive signal to investors. Investors always pay attention to the rate of return on capital. Dividend policy is expected to be in line with shareholder expectations. The relationship between dividend policy and firm value can be formulated as a third hypothesis: Dividend policy has a significant effect on firm value.

The research was conducted using the property and real estate industries listed on the Indonesia Stock Exchange (IDX). Competition in the property and real estate industry is very dominating and makes every company increasing improve operational performance so that its goals can be achieved. The main purpose of a public company is to provide prosperity for the owners or shareholders by increasing the value of the company. Property and real estate companies are companies engaged in the construction of land and buildings along with facilities and infrastructure as complements. In Indonesia, there are companies engaged 
in property and real estate such as Ciputra Development, Agung Podomoro, Lippo and others. This time, Property and real estate companies have become one of the investments that are very popular with many people, this is also supported by the demographic conditions of Indonesia which has a very large population of 270.2 million people in 2020 [36]. The following is a chart of the property and real estate industry stock prices in 2018-2020:

Fig 1.Property and Real Estate Sector Stock Price Growth in 2018-2020

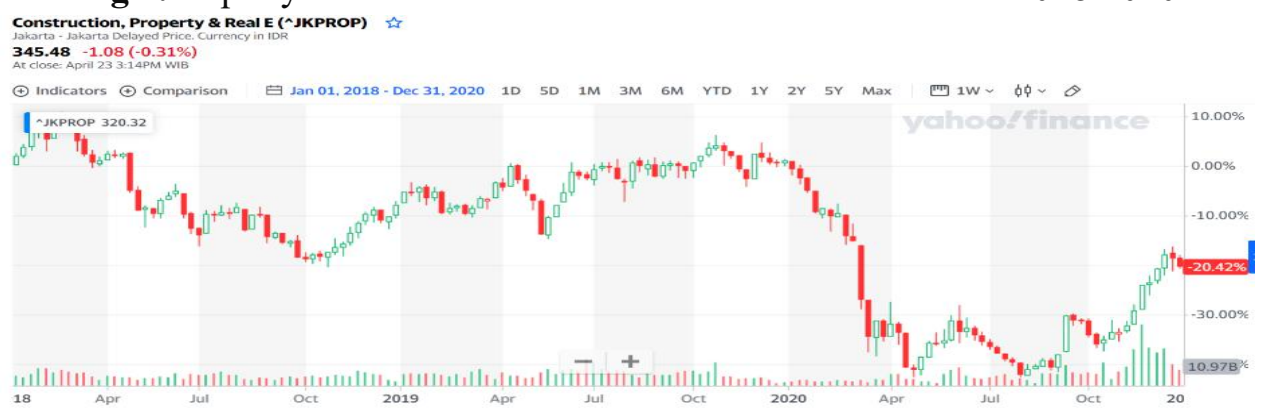

Data source: Yahoo! finance. 2020

The growth of share prices in the property and real estate sectors from 2018 to 2020 experienced a downward trend. In 2018 the share price increased and was relatively stable until 2019. In 2020 the share price of property and real estate decreased by $40 \%$. The downward trend in 2020 occurred due to the COVID-19 pandemic that hit Indonesia. The COVID-19 pandemic has not only affected the property and real estate sectors, but all sectors on the IDX in the first quarter of 2020 (cnbcindonesia.com). When there is high economic growth, the property and real estate industry experiences a boom and tends to be oversupplied. When economic growth declines, this sector will experience a drastic decline as well. However, it can be seen that in mid-2020 until now, Property and real estate share prices have consistently increased which shows that investment in this sector is very promising and is still attracting attention in line with the increasing even handling of Covid-19. High stock prices make the company value high and increase market confidence not only in the company's current performance but also on future prospects [37].

\section{METHODS}

This type of research is causal associative research. According to [38] causal associative research is research that aims to determine the effect of each variable on one another. The research population is property and real estate companies listed on the Indonesia Stock Exchange in 2018 - 2020, totaling 64 companies [36]. The sample is part of the population taken through certain ways and has certain characteristics [38]. Sampling using purposive sampling. The criteria for selecting the research sample are as follows: (1) Property and real estate sub-sector companies that are listed and consistent on the Indonesia Stock Exchange for the 2018-2020 period, (2) consistently earn profits for the 2018-2020 period, and (3) consistently distribute dividends for the 2018-2020 period. Based on the sample selection procedure, the number of samples obtained is 33 companies.

The type of data is quantitative data that is numerical which can be processed and analyzed using statistics. Quantitative data are financial statements of property and real estate sub-sector companies listed on the Indonesia Stock Exchange for the 2018-2020 period. Sources of data are secondary data in the form of evidence, records or historical reports that are arranged for publication or not. The research data source is the financial statements of the property and real estate sub-sector companies listed on the Indonesia Stock Exchange for the 2018-2020 period from [36]. The data collection technique is documentation, namely the financial statements of companies in the property and real estate sub-sectors listed on the Indonesia stock exchange for the 2018-2020 period.Operational definition is an explanation of the definition of the variable that has been selected and the measurement of the variable needs to be determined to obtain the right value for that variable.

a. The value of the company is the company's performance as reflected by the stock price formed by the demand and supply of the capital market which reflects the public's assessment of the company's 
performance. Company value is proxied using price to book value (PBV). According to [39] PBV formula which is the price per share divided by the book value per share.

b. Leverage ratio is a ratio to measure the company's assets financed by debt. Leverage is proxied by debt to equity ratio (DER). According to [40] the DER formula is total liabilities divided by total equity.

c. The profitability ratio is used to measure the level of business efficiency and profitability achieved by the bank concerned. Profitability is proxied using return on equity (ROE). According to [40] the formula for ROE is net income after tax divided by total equity.

d. Dividend policy is a decision whether the profits earned by the company will be distributed to shareholders as dividends or will be retained in the form of retained earnings to finance investment in the future. Dividend policy is proxied using the dividend payout ratio (DPR). According to [41] the DPR formula is dividends per share divided by earning per share.

\section{RESULT AND DISCUSSION}

\section{Descriptive Statistics}

Descriptive statistical analysis is a procedure for compiling and presenting data collected in a research with the aim of getting a picture or describing a set of observational data so that it is easy to understand, read, and use as information [38].

Table 1. Descriptive Statistics

\begin{tabular}{|l|c|r|r|r|rr|}
\hline & $\mathrm{N}$ & \multicolumn{1}{|c|}{ Minimum } & Maximum & mean & \multicolumn{2}{|c|}{ Std. Deviation } \\
\hline Leverage & 33 & .00 & 2.20 & .7006 & .56247 \\
\hline Profitability & 33 & .01 & .24 & .1024 & .05483 & .34281 \\
\hline Dividend policy & 33 & .00 & 1.52 & .3061 & .93877 \\
\hline Firm Value & 33 & .41 & 4.73 & 1.3124 & & .03 \\
\hline
\end{tabular}

The amount of data is 33 samples studied during the 2018-2020 period. The dependent variable is firm value (PBV) and the independent variables include leverage (DER), profitability (ROE), and dividend policy (DPR).

1. The leverage variable has the lowest value of $0.00 \%$, meaning that the lower the DER value, the smaller the debt owned, and the highest value of $2.00 \%$, meaning that the greater the DER value, the higher the risk of the company because debt is higher than capital. With an average of $0.7006 \%$, it describes the high own capital owned and the minimum debt is below 1 and a standard deviation of $0.56247 \%$. The standard deviation is lower than the average value, indicating that there is a gap between the highest and lowest DER.

2. The profitability variable has the lowest value of $0.01 \%$, meaning that the lower the ROE value, the smaller the net profit generated by the company from the capital owned, and the highest value of $0.24 \%$, meaning the greater the ROE value, the higher the net profit generated by the company. With an average of $0.1024 \%$, the company's net profit generated from its own capital is very high and the standard deviation is $0.05483 \%$. The standard deviation is lower than the mean value indicating that there is a gap between the highest and lowest ROE.

3. The dividend policy variable has the lowest value of $0.00 \%$, meaning that the amount of dividends distributed by the company is small, and the highest value of $1.52 \%$ means that the amount of dividends distributed is large. With an average of $0.3061 \%$, the dividend distribution is not good enough because it is less than 1 and the standard deviation is $0.34281 \%$. A standard deviation higher than the average value indicates that there is no gap between the highest and lowest DPR.

4. The variable value of the company has the lowest value of $0.41 \%$, which means the lower the market trust in the company, and the highest value of $4.73 \%$ describes the company as having a high value and gaining the trust of investors. With an average of $1.3124 \%$, it shows the company has good value and is still in demand by investors to invest because it is more than 1 and the standard deviation is $0.93877 \%$. A standard deviation lower than the mean value indicates a gap between the highest and lowest PBV. 


\section{Normality Test Data}

Testing the normality of the data using the one Sample Kolmogorov-Smirnov test. Data is defined as normally distributed if the significance value is more than 0.05 (Sig 0.05). From the tests carried out, the results of the Kolmogorov-Smirnov value or statistical test were 0.148 with a significance value of 0.060 . The significance value of 0.060 is greater than 0.05 , meaning that the residual data is normally distributed and meets the assumption of normality.

\section{Multicollinearity Test}

The multicollinearity test aims to test a regression model whether it has symptoms of multicollinearity and can be seen in the VIF value. The regression model is said to be good and there is no multicollinearity if the VIF value is $<10$. The results of the multicollinearity coefficients test show that the VIF value of the DER variable is 1.249 , the ROE variable is 1.191 , and the DPR variable is 1.060 . The four variables have a value close to 1 , so there is no multicollinearity symptom. The VIF value of the four variables is less than 10 , so it is concluded that there is no multicollinearity between the independent variables.

\section{Autocorrelation Test}

Auto correlation is the correlation between members of the observation that is arranged according to time and place [38]. A good regression model is one that is free from autocorrelation. To find out the symptoms of autocorrelation, the Durbin-Watson (DW) test can be used with the test results that the DurbinWatson (DW) value is 1.388 . So it can be concluded that in this regression model there is no autocorrelation because the DW value is between -2 and +2 or $-2>1.3882$.

\section{Heteroscedasticity Test}

Heteroscedasticity is a residual variance that is not the same for all observations in the model [38].A good regression is one that does not occur heteroscedasticity. Heteroscedasticity test using Spearman's rho correlation method. The test uses a significance level of more than 0.05 , so it is said that there is no heteroscedasticity. Spearman's rho correlation results show that Sig. (2-tailed) the DER variable is 0.444 , the ROE variable is 0.980 , and the DPR variable is 0.603 . So it can be concluded that from the three variables the value of Sig. (2-tailed) is more than 0.05 , so it can be said that there is no heteroscedasticity symptom.

\section{Multiple Regression Analysis}

Multiple regression analysis is an analysis that connects two or more independent variables with the dependent variable which aims to measure the intensity of the relationship between two or more variables. Multiple regression analysis results:

Table 2. Multiple regression

\begin{tabular}{|c|c|c|c|c|c|c|c|}
\hline \multirow{2}{*}{ Model } & \multicolumn{2}{|c|}{$\begin{array}{l}\text { Unstandardized } \\
\text { Coefficients }\end{array}$} & \multirow{2}{*}{$\begin{array}{c}\text { Standardized } \\
\text { Coefficients }\end{array}$} & \multirow[t]{2}{*}{$\mathrm{t}$} & \multirow{2}{*}{ Sig. } & \multicolumn{2}{|c|}{$\begin{array}{l}\text { Collinearity } \\
\text { Statistics }\end{array}$} \\
\hline & B & Std. Error & & & & Tolerance & VIF \\
\hline (Constant) & -.395 & .308 & & -1.285 & .209 & & \\
\hline DER & .078 & .183 & .082 & .429 & .671 & .801 & 1,249 \\
\hline ROE & 4.117 & 1,831 & .419 & 2,249 & .032 & .840 & 1.191 \\
\hline DPR & .088 & .276 & .056 & .318 & .752 & .943 & 1.060 \\
\hline
\end{tabular}

\section{Coefficient of Determination $\left(\mathbf{R}^{2}\right)$}

The coefficient of determination $\left(\mathrm{R}^{2}\right)$ is used to measure the model's ability to explain the variation of the independent variable to the dependent variable and can be said to be the proportion of the influence of all independent variables on the dependent variable [38]. The results of the coefficient of determination $\left(\mathrm{R}^{2}\right)$ in table 3 obtained the number $\mathrm{R}^{2}$ of 0.069 or $6.9 \%$. This shows that DER, ROE, and DPR have an influence on firm value of $6.9 \%$, while the remaining $93.1 \%$ is influenced by other variables not included in this model. 
Table 3. Coefficient of determination

\begin{tabular}{|l|l|r|r|r|}
\hline Model & $\mathrm{R}$ & R Square & $\begin{array}{c}\text { Adjusted R } \\
\text { Square }\end{array}$ & Std. Error of the Estimate \\
\hline 1 & $.395 \mathrm{a}$ & 156 & .069 & .52030 \\
\hline
\end{tabular}

\section{The Effect of Leverage on Company Value}

Based on the results of hypothesis testing in table 2 shows the value of $t$ count $(0.429)<t$ table (2.04227) with a significance level of $0.671>0.05$. Based on the comparison test between $t$ count and t table as well as the significance value, $\mathrm{H}_{1}$ is rejected. This means that the independent variable (debt to equity ratio) has no effect on firm value. Leverage measures the company's ability to pay off debt, both long-term and short-term. DER is a ratio that measures the company's ability to pay off all debt with its own capital. A high DER value indicates that the debt owned by the company is higher than its own capital and this is in line with the signal theory which states that a high level of leverage will give a negative signal to investors because a high level of debt will increase the risk of the company. The use of large debt has an impact on the greater the risk that will have a negative effect on the value of the company. In this study, investors do not see the level of debt owned by the company because investors are more concerned with how the company utilizes the funds owned by the company effectively to generate company profits. The company's management must take advantage of the debt they have. The results of this study support the research [12], [13], [14], [15], [16], [17], [18], and [19] who also found that leverage had no effect on firm value. However, the results of this study contradict the research of [4], [5], [6], [7], [8], [9], [10], and [11] that leverage has an effect on firm value.

\section{The Effect of Profitability on Firm Value}

Based on the results of hypothesis testing in table 2 shows the value of $t$ count $(2.249)>t$ table (2.04227) with a significance level of $0.032<0.05$. Based on the comparison test between $t$ count and $t$ able and the significance value, $\mathrm{H}_{2}$ is accepted. This means that the independent variable (return on equity) has an effect on firm value. Profitability describes the company's ability to generate profits from company activities. ROE is a ratio that measures the company's ability to generate net income through the use of its own capital. A high ROE value gives a positive signal to investors because the company is getting better at generating profits from its own capital and the owner's position is getting stronger. Investors are very concerned about the company' s profitability to assess whether the company is worthy of investment. So that high profitability will make investors invest in the company and will provide added value to the value of the company. The results of this study support the research of [13], [7], [20], [21], [22], [18], [23], [16], [9], [19], [5] and [8] that profitability has an effect on firm value. The results of this study contradict the research of [17], [24], [12], [25], and [10] that profitability has no effect on firm value.

\section{The Effect of Dividend Policy on Firm Value}

Based on the results of hypothesis testing in table 2 shows the value of $t$ count $(0.318)<t$ table (2.04227) with a significance level of $0.752>0.05$. Based on this test, $\mathrm{H}_{3}$ is rejected, meaning that the independent variable (dividend payout ratio) has no effect on firm value. Dividend policy is a decision whether the profit earned by the company will be distributed to shareholders as dividends or retained in the form of retained earnings to finance investment in the future. The higher the value of the DPR, the higher the investor's perception of the value of the company. High dividend distribution will be a benchmark for investors to determine investment decisions in the company. In determining the dividend policy, it is very important but also pay attention to the stability of dividend payments for the long term. In this study, the value of the company is not determined by dividend payments but depends on the earning power of the assets owned by the company. The company's capital will increase due to a decrease in dividend payments. Investors pay more attention to the company's ability to generate profits and how to manage profits for the benefit of the future rather than paying high dividends each period. Therefore, the company's policy in managing dividends is not the only important benchmark for investors in assessing the company. The results of this study support of [17], [24], [12], [25], and [10] that dividend policy had no effect on firm value. The 
results of this study contradict the research of [28], [12], [29], [22], [30], [24], [31], [32], [9], [12], [18], [33], [27], [14], and [34] that dividend policy affects firm value.

\section{CONCLUSION}

Based on data analysis, hypothesis testing and discussions that have been carried out on property and real estate sector companies listed on the Indonesia Stock Exchange in 2018-2020, it can be concluded as follows: (1) Leverage has no effect on firm value. This condition illustrates that the size of the debt owned by the company against its own capital has no influence on investors in assessing the company. (2) Profitability has an effect on firm value. The company's ability to earn profits is the main benchmark for investors in considering whether the company has a high or low value to invest. (3) Dividend policy has no effect on firm value. Investors would pay more attention to the company's ability to earn profits and make the good decision of use profits for the company today and in the future.

Firm value is an investor' s perception of the company, so it is important for the company to increase investor confidence. The results of the study are expected to be a reference by management by increasing the company's net profit because it is the main reference for investors to decide on investment rather than how much leverage or dividend policy disclosures are.Suggestions for further research: (1) expand research and develop the population not only in property and real estate sector companies but also in other sector companies listed on the Indonesia Stock Exchange so that research results can be generalized, (2) increase the research period of more than 3 years, and (3) changing or adding research variables related to firm value of liquidity, managerial ownership, institutional ownership, investment opportunity, and firm size so as to increase the adjusted $\mathrm{R}$ square value.

\section{REFERENCES}

[1] R. A. I. Sari, Priyadi, and M. P. Priyadi, "Pengaruh Leverage, Profitabilitas, Size, Dan Growth Opportunity Terhadap Nilai Perusahaan," J. Ilmu dan Ris. Manaj., vol. 5, no. 10, pp. 2-17, 2016.

[2] STEPHEN ROSS, "The Determination Of Financial Structure: The Incentive Signalling Approach,” Bell J. Econ., vol. 8, no. 1, pp. 23-40, 1977.

[3] J. F. Brigham, Eugene F. dan Houston, Fundamental of Financial Management, 13th ed. Cengage Learning, 2013.

[4] T. Setyabudi, "The Effect of Institutional Ownership, Leverage, and Profitability on Firm Value with Dividend Policy as an Intervening Variable,” J. Bus. Manag. Rev., vol. 2, no. 7, pp. 457-469, 2021, doi: $10.47153 / \mathrm{jbmr27.1632021.}$

[5] I. Aprilyani, M. T. H. Widyarti, and N. Hamidah, "The Effect Of ERM, Firm Size, Leverage, Profitability And Dividend Policy On Firm Value," vol. 4, no. 1, pp. 65-75, 2021.

[6] F. C. Febriyanto, "the Effect of Leverage, Sales Growth and Liquidity To the Firm Value of Real Estate and Property Sector in Indonesia Stock Exchange," Eaj (Economics Account. Journal), vol. 1, no. 3, p. 198, 2018, doi: 10.32493/eaj.v1i3.y2018.p198-205.

[7] J. F. Markonah Markonah, Agus Salim, "PENGARUH PROFITABILITAS, LEVERAGE, DAN LIKUIDITAS UNTUK NILAI PERUSAHAAN Markonah,” vol. 1, no. 1, pp. 83-94, 2020, doi: 10.31933/DIJEFA.

[8] D. R. Sutama and E. Lisa, "PENGARUH LEVERAGE DAN PROFITABILITAS TERHADAP NILAI PERUSAHAAN (Studi pada Perusahaan Sektor Manufaktur Food and Beverage yang terdaftar di Bursa Efek Indonesia)," Sains Manaj. dan Akunt., vol. X, no. 2, pp. 65-85, 2018.

[9] F. Prasetya Margono and R. Gantino, "Influence of Firm Size, Leverage, Profitability, and Dividend Policy on Firm Value of Companies in Indonesia Stock Exchange," Copernican J. Financ. Account., vol. 10, no. 2, pp. 45-61, 2021, doi: 10.12775/cjfa.2021.007.

[10] N. K. dan H. M. Khumairoh, "Pengaruh Leverage, Profitabilitas, dan Ukuran Perusahaan Terhadap Nilai Perusahaan.," Syariah Pap. Account. FEB UMS, 2016.

[11] D. Lubis, L. Siregar, J. Jubi, and A. Astuti, "Pengaruh Leverage Dan Profitabilitas Terhadap Nilai Perusahaan Pada Perusahaan Sub Sektor Kimia Yang Terdaftar Di Bursa Efek Indonesia," SULTANIST J. Manaj. dan Keuang., vol. 6, no. 1, pp. 63-69, 2018, doi: 10.37403/sultanist.v6i1.115.

[12] V. R. Putri and A. Rachmawati, "The Effect of Profitability, Dividend Policy, Debt Policy, and Firm Age on Firm Value in The Non-Bank Financial Industry,” J. Ilmu Manaj. Ekon., vol. 10, no. 1, p. 14, 2018, doi: 10.35384/jime.v10i1.59. 
[13] G. P. Tahu and D. D. B. Susilo, "Effect of Liquidity, Leverage and Profitability to The Firm Value (Dividend Policy as Moderating Variable) in Manufacturing Company of Indonesia Stock Exchange," Res. J. Financ. Account., vol. 8, no. 18, pp. 89-98, 2017.

[14] L. Fujianti, A. K. Hubbansyah, S. Siswono, and L. Sinaga, "The Effect of Profitability, Leverage, Institutional Ownership, Managerial Ownership, and Dividend Policy on Firm Value: The Indonesia Stock Exchange Cases," J. Glob. Bus. ..., vol. 1, no. December, pp. 40-54, 2020, [Online]. Available: http://journal.univpancasila.ac.id/index.php/INQUISITIVE/article/view/1860.

[15] I. Sihombing, Lasminar; Widia Astuty, "The Effect of Funding Decisions and Intellectual Capital on Firm Value with Profitability as an Intervening Variable in Manufacturing Companies Listed on the Indonesia Sharia Stock Index,” Int. J. New Technol. Res., vol. 6, no. 7, pp. 6585-6591, 2020, doi: 10.31871/ijntr.6.7.12.

[16] K. Khuzaini, D. W. Artiningsih, and L. Paulina, "Influence of Profitability, Investment Opportunity Set (Ios) Leverage and Dividend Policy on Firm Value in The L Service in Indonesia Stock Exchange,” J. Terap. Manaj. Dan Bisnis, vol. 3, no. 2, p. 235, 2017, doi: 10.26737/jtmb.v3i2.346.

[17] R. H, R., Sugiastuti, M, Dzulkirom, \& M, S., "RJOAS, 8(80), August 2018," Russ. J. Agric. Socio-Economic Sci. 80(8)88-96, vol. 8, no. 80, pp. 160-166, 2018.

[18] A. Banani, R. Dewi, and Sulistyandari, “The Effect of Leverage, Liquidity, Profitability, Firm's Growth, Firm's Size, and Dividend Policy toward Firm Value (Study at Manufacture Companies Listed on Indonesia Stock Exchange Period 2014-2017)," J. Akuntansi, Manaj. dan Ekon., vol. 23, no. 2, pp. 8-19, 2021, [Online]. Available: http://jos.unsoed.ac.id/index.php/jame/article/view/4469/2473.

[19] A. G. A. Kanta, Hermanto, and N. K. Surasni, "The Effect of Leverage and Profitability on Firm Value with Dividend Policy as Moderation Variable (Studies in Manufacturing Companies for the 2014-2018 Period)," Int. J. Multicult. Multireligious Underst., vol. 8, no. 1, pp. 245-255, 2021.

[20] D. Kristianti and J. E. H. J. Foeh, “The Impact Of Liquidity And Profitability On Firm Value With Dividend Policy As An Intervening Variable (Empirical Study Of Manufacturing Companies In The Pharmaceutical Sub Sector Listed On The Indonesia Stock Exchange In 2013-2017),” J. Bisnis dan Kewirausahaan, vol. 16, no. 1, pp. 65-78, 2020, doi: 10.31940/jbk.v16i1.1829.

[21] I. Zuhroh, "The Effects of Liquidity, Firm Size, and Profitability on the Firm Value with Mediating Leverage," KnE Soc. Sci., vol. 3, no. 13, p. 203, 2019, doi: 10.18502/kss.v3i13.4206.

[22] W. Yuwono and D. Aurelia, "The Effect of Profitability, Leverage, Institutional Ownership, Managerial Ownership, and Dividend Policy on Firm Value,” J. Glob. Bus. Manag. Rev., pp. 15-29, 2021, doi: 10.37253/jgbmr.v3i1.4992.

[23] F. B. Dwi Vina Rahmawati, Akhmad Darmawan, Feti Setyarini, "Profitability, Capital Structure and Dividend Policy Effect on Firm Value Using Company size as a moderating variable (In the Consumer Goods Industry Sector Companies listed on the Indonesia Stock Exchange (IDX) during 2015 - 2019 Periods), Int. J. Econ. Bus. Account. Res., vol. 5, no. 1, pp. 282-292, 2021.

[24] R. Septiani, P. D. Paramita, and M. A. Putri, "The Influence of Profitability and Debt Policy to Firm Value with Dividend Policy as Intervening Variable (A Case Study of a Manufacturing Company in Indonesia's Stock Exchanges 2012-2016)," J. Account., vol. 4, no. 4, pp. 1-20, 2018, [Online]. Available: http://jurnal.unpand.ac.id/index.php/AKS/article/view/970.

[25] P. Putranto and E. Kurniawan, "Effect of managerial ownership and profitability in firm value," Eur. J. Bus. Manag., vol. 10, no. 25, pp. 96-104, 2018.

[26] M. Priya, Vidhya P dan Mohanasundari, "Devidend Policy and Its Impact on Firm Value: A review Theoris and Empirical Evidence,” Dep. Manag. Stud., vol. 3, no. 3, 2016.

[27] S. Maggee, "Pengaruh Kebijakan Dividen Terhadap Nilai Perusahaan yang Tercatat pada Indeks LQ-45 Bursa Efek Indonesia," J. Wira Ekon. Mikroski, vol. 6, no. 1, pp. 73-84, 2016.

[28] Y. C. dan F. I. Ivansyah, "Pengaruh Kebijakan Dividen, Pertumbuhan Penjualan, dan Ukuran Perusahaan Terhadap Nilai Perusahaan,” J. Ilmu dan Ris. Akunt., vol. Vol.7, no. No.9, 2018.

[29] R. Hasanuddin, “The Influence of Investment Decisions, Dividend Policy and Capital Structure on Firm Value," J. Econ. Resour., vol. Vol.4, no. Issue 1, 2021.

[30] A. F. dan B. J. Odinya, "The Effect Of Dividend Policy on the Value of Firms Listed at the Nairobi Securitues Exchange," African Delelopment Financ. J., vol. Vol.2, no. No.1, 2018.

[31] A. E. Irawati and E. F. Komariyah, "The Role of Capital Structure on The Effect of Dividend Policy and Business Risk on Firm Value (Evidence from Indonesian Manufacturing Company)," Indones. J. Account. Res., vol. 22, no. 02, pp. 207-228, 2019, doi: 10.33312/ijar.463.

[32] G. Agung, S. Hasnawati, and R. A. F. Huzaimah, "The Effect of Investment Decision, Financing Decision, 
Dividend Policy on Firm Value,” J. Bisnis dan Manaj., vol. 17, no. 1, pp. 1-12, 2021, doi: 10.23960/jbm.v17i1.189.

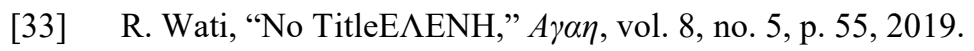

[34] D. C. Ovami and A. A. Nasution, "Pengaruh Kebijakan Dividen Terhadap Nilai Perusahaan yang Terdaftar dalam Indeks LQ 45," Own. (Riset dan J. Akuntansi), vol. 4, no. 2, p. 331, 2020, doi: 10.33395/owner.v4i2.247.

[35] N. Juhandi, M. Fahlevi, M. N. Abdi, and R. Noviantoro, "Liquidity, Firm Size and Dividend Policy to the Value of the Firm (Study in Manufacturing Sector Companies Listed on Indonesia Stock Exchange)," vol. 100, no. Icoi, pp. 313-317, 2019, doi: 10.2991/icoi-19.2019.53.

[36] “https://www.bps.go.id/pressrelease/2021/01/21/1854/hasil-sensus-penresident-2020.html,” 2020. .

[37] I. G. A. A. Jayaningrat, M. A. Wahyuni, and E. Sujana, "Pengaruh Leverage, Profitabilitas, Likuiditas, Kebijakan Deviden, Kepemilikan Manajerial, Dan Kepemilikan Institusional Terhadap Nilai Perusahaan Pada Perusahaan Properti Dan Real Estate Di Bursa Efek Indonesia Tahun 2013-2015," E-Journal S1 Akunt. Univ. Pendidik. Ganesha, vol. 7, no. 1, pp. 1-12, 2017.

[38] S. Bahri, Metodologi Penelitian Bisnis; Lengkap dengan teknik pengolahan data SPSS, 1st ed. Yogyakarta: Penerbit Andi Yogyakarta, 2018.

[39] C. J. Gitman, L.J., Zutter, Principles Of Managerial Finance, 13th ed. Pearson. Boston., 2012.

[40] Muslichah dan Syaiful Bahri, Akuntansi Manajemen Teori dan Aplikasi, 1st ed. Jakarta: Mitra Wacana Media, 2021.

[41] S. Bahri, "Faktor-faktor yang mempengaruhi Kebijakan Dividen," J. Ris. Akunt. dan Komputerisasi Akunt., vol. 8, no. 1, pp. 63-84, 2017. 